\title{
The Effect of the Use of Kinetic Sand as a Stimulation Media for Fine Motor Development in Preschool Children at Ra Al-Masithoh Karangploso
}

\author{
Imas Fideli Pragistha* and Herawati Mansur and Reni Wahyu Triningsih
}

D-IV Midwifery Study Program, Department of Midwifery, Politeknik Kesehatan Kemenkes Malang

E - mail : official.imas@gmail.com*

\begin{abstract}
Fine motor skill is a developmental aspect that focuses on the ability of certain eye and limb coordination. To optimizing improvement children's motor skills, stimulation is necessary. The purpose of this study was to determine the effect of the use of kinetic sand as a stimulation media for fine motor development in preschool children. This study uses a pre-experimental type one group pretest-posttest design. The sampling technique used was purposive sampling with a sample of 21 respondents. The results of the measurement of fine motor skills before getting stimulation most of the children (65.2\%) included in the category of not yet capable while after getting stimulation most of the respondents (73.91\%) were in the category of being able. Wilcoxon's Signed Rank Test statistic test results show that $\alpha=0.05$. The results of the analysis show that $\rho$-value has a value of $0.000(\rho<0.05)$, so that H1 is acceptedd. Therefore, it can be stated that there is an effect of the use of kinetic sand as a stimulation medium for fine motor development in preschool children. It is expected that parents who have preschool children can make kinetic sand as a medium for stimulating fine motor development.
\end{abstract}

Keywords: Children Development, Kinetic sand, Fine Motor Skills

\section{INTRODUCTION}

Development is the result of the interaction between the maturation of the central nervous system and the organs it affects. is a continuous process from conception to adulthood (Susilaningrum, 2013). Development has an important role in the formation of a person both physically and psychosocially. If in the development process a person does not go well or experiences delays, this can affect the next stage.

Development consists of several dimensions, including the dimensions of mental or cognitive development, psychomotor development consisting of gross and fine motor, social development, emotional development, and language development (Suherman, 2012).

Fine motor skills are the development of controlling physical movements that require hand and eye coordination such as drawing, writing, cutting (Marmi, 2015). Fine motor development is needed by children to take care of themselves. In addition, mastery of skills in the use of hands can be a capital for children to learn other new things. Fine motor skills are also related to cognitive development as it involves the visual perception and analytical skills of the child in the process. Often parents do not realize that their child has developmental delays.

The 2014 Indonesian Health Profile states that in Indonesia the number of children aged 0-2 years is $14,228,917$ people, while the number of toddlers aged 1-4 years is $19,388,791$ people. As many as $16 \%$ of these toddlers experienced neurological and brain development disorders ranging from mild to severe. Approximately 5$10 \%$ are thought to have developmental delays that have no apparent cause. It is estimated that 1$3 \%$ of toddlers experience general developmental delays which include motor, language, social emotional, and cognitive development (Ministry of Health, 2016). 
Based on data obtained from a preliminary study at the Malang District Health Office, the coverage of SDIDTK in 2017 was 164,213 children and $291(0.1 \%)$ of them were detected as having deviations. Sumbermanjing Wetan District was ranked first with a percentage of $14.6 \%$ or 146 of 711 children. The second rank is occupied by Tirtoyudo District, which is around $4.25 \%$. Followed by Pujon Regency (1.0\%) in third place and Wajak Regency $(0.57 \%)$ in fourth place. While in the fifth rank is occupied by Karangploso District with a percentage of $0.53 \%$.

One of the efforts that can be done to stimulate children's development is to provide stimulation. Giving stimulation to children can be given by playing. Play and children are an inseparable unit. Play is one of the efforts that can be done to stimulate children's development. In Indonesia in 2012 the number of children who were given educational games in 2009 reached 23,000 , in 2010 it reached 24,120 and in 2011 it reached 25,100 . Stimulation of play in children is very helpful for children's development from an early age, with good parental knowledge, the needs of children's growth and development will be met (Kemenkes RI, 2012).

The results of a preliminary study conducted at RA Al-Masitoh, found that 2 out of 5 children really like sand games. The rest said they were reluctant because they felt dirty and disgusted. Whereas playing using natural media such as sand can help stimulate fine motor skills in children. Therefore, innovation is needed in the form of educational game tools to increase children's interest in honing their fine motor skills.

The kinetic sand educational game tool is a synthetic sand toy coated with polydimethylsiloxane which makes the sand texture flexible, but not sticky either in the hands or in the play area. This sand is very easy to shape like plasticine and does not limit children's imagination. Children can freely make the desired shape, either by hand or mold. This toy is relatively new and has not been widely used as a learning medium for early childhood. Therefore, the authors are interested in examining the effect of using kinetic sand educational games as a medium of stimulation on fine motor development in preschoolers.
The purpose of this study was to determine the effect of using kinetic sand educational games as a medium of stimulation on the fine motor development of preschool children.

\section{METHODS}

The research design used in this study was the Pre-Experimental One Group Pretest-Postest Design. The population in this study were all students of class A Kindergarten RA Al-Masitoh for the 2018/2019 academic year as many as 27 children. The sampling technique used was purposive sampling and the number of samples obtained was 21 children.

The inclusion criteria in this study were the inclusion criteria in this study were: Children aged 4-5 years at the time of data collection, present at the time of data collection, mother was a housewife, and received parental approval to become respondents. This research was conducted at RA Al-Masitoh Kindergarten, Tegal Gondo Village, Karangploso District, Malang Regency on August 13 - September 12018.

The research instrument used the Kindergarten Fine Motor Skills Observation Sheet. The data collection process was carried out by measuring the child's early fine motor skills (Pretest) then being stimulated for 90 minutes for 9 meetings and then repeating the measurements using the same instrument. Data analysis using Wilcoxon Signed Rank Test.

\section{RESULTS AND DISCUSSION}

Characteristics of respondents based on gender showed that the majority of respondents were male, namely $57.1 \%$.

Based on the education level of the parents, it is known that most of the respondents' parents $(57.1 \%)$ are junior high school graduates and a small proportion (9.5\%) are college graduates.

Table 1. Results of Measurement of Fine Motor Ability of Preschool Children Before Getting Stimulation

$\begin{array}{ccc}\begin{array}{c}\text { Children's Fine Motor } \\ \text { Ability }\end{array} & \text { f } & \text { \% } \\ \text { Already able } & 2 & 9,5 \\ \text { Capable enough } & 6 & 26,1\end{array}$




\begin{tabular}{ccc}
\hline $\begin{array}{c}\text { Children's Fine Motor } \\
\text { Ability }\end{array}$ & f & \% \\
Has not been able to & 13 & 65,2 \\
Total & $\mathbf{2 1}$ & $\mathbf{1 0 0}$ \\
\hline
\end{tabular}

(Source: Data Khusus Penelitian 2018)

Table 1 shows that most respondents (65.2\%) have not been able to master fine motor skills and a small proportion (9.5\%) are classified as capable.

Table 2. Results of Measurement of Fine Motor Ability of Preschool Children After Getting Stimulation

\begin{tabular}{ccc}
\hline $\begin{array}{c}\text { Children's Fine Motor } \\
\text { Ability }\end{array}$ & f & $\mathbf{\%}$ \\
Already able & 17 & 73,91 \\
Capable enough & 4 & 21,74 \\
Total & $\mathbf{2 1}$ & $\mathbf{1 0 0}$ \\
\hline
\end{tabular}

(Source: Data Khusus Penelitian 2018)

Table 2 showed that after being stimulated using kinetic sand, most of the children (73.91\%) were in the capable category.

Table 3. Cross Distribution of Fine Motor Ability Levels of Preschool Children Before and After Getting Stimulation Using Kinetic Sand

\begin{tabular}{ccccc}
\hline $\begin{array}{c}\text { Children's } \\
\text { Fine Motor }\end{array}$ & $\mathbf{f}$ & $\mathbf{\%}$ & & \\
$\quad$ Ability & & & & \\
Already able & 2 & 9,5 & 17 & 73,91 \\
Capable enough & 6 & 26,1 & 4 & 21,74 \\
Has not been & 13 & 65,2 & 0 & 0 \\
able to & $\mathbf{2 1}$ & $\mathbf{1 0 0}$ & $\mathbf{2 1}$ & $\mathbf{1 0 0}$ \\
$\quad$ Total &
\end{tabular}

(Source: Data Khusus Penelitian 2018)

Table 3. This shows that the percentage of respondents in the poor category before being stimulated using kinetic sand was greater $(65.2 \%)$ than respondents in the capable category. After being given stimulation using kinetic sand, the number of respondents in the capable category was greater $(73.91 \%)$ than respondents in the less category $(0 \%)$.

Hypothesis testing using the Wilcoxon Signed Rank Test statistical test with a significance level of \&lt;0.05. From the calculation results obtained a significance of 0.000005 . Because the value $<0.05$ then $\mathrm{H} 1$ is accepted and it can be said that there is an effect of using kinetic sand as a stimulation medium on fine motor development in preschool-aged children at RA Al-Masitoh

The discussion in the article aims to answer the formulation of the problem and research questions, show how the findings were obtained, explain the meaning of the research results, how the reported research results can solve problems, differences and similarities with previous research and the possibility of its development.

Development is an increase in the body's structural and functional ability to perform complex activities. This process occurs continuously throughout human life and continues. This means that each stage of development is interrelated and can influence the next stage. Although development is a natural process, it cannot be left alone. Proper supervision and direction is needed in order to develop optimally, especially for children aged 3-5 years. This is because at that age a person will experience very rapid brain development so it is easy to accept new things. It would be a shame if at that time it was not used to improve child development.

Several studies have shown that giving the right stimulation can help optimize the process of child development. In addition, the provision of stimulation must be done in a fun way so that children are more motivated to continue to develop. As we know, the world of children cannot be separated from playing. Play is an activity that is done voluntarily for pleasure. Stimulation packaging using play activities aims to motivate children so that children do not feel forced to do certain activities. This is in accordance with the opinion of Karl Gross that playing is very useful for acquiring and practicing certain skills and is very important for their lives as adults. In addition, several studies have also shown that the provision of play stimulation has a positive relationship to child development. The development that occurs is in accordance with the form of stimulation given.

Kinetic Sand is a relatively new educational game tool on the market. This sand is a cross between synthetic sand and 
polydimethylsiloxane or better known as silicon. The result of this mixing causes synthetic sand to have a flexible and easy to shape texture similar to plasticine. This sand is a fairly new learning medium and has not been widely used in Indonesia. Even until now there has not been much research on the use of this sand. According to the results of research conducted by Wahyuni (2014) plasticine can develop fine motor skills in kindergarten students. In terms of shape and how to use Kinetic Sand has a shape and method of use that is almost similar to plasticine. So it is expected that the use of Kinetic Sand can also affect the development of children, especially in their fine motor skills.

Before providing play stimulation using Kinetic Sand, the researcher first measured the respondents' fine motor skills. This is done with the aim that researchers can find out a description of the respondents' initial abilities so that researchers can compare the condition of respondents before and after being given stimulation. The respondents' fine motor skills were measured by using the guidelines for observing the fine motor skills of kindergarteners. The observed abilities included the child's ability to use writing tools, perform manipulative movements, compose simple puzzles, arrange cubes, perform basic activities such as squeezing, tearing and putting on their own clothes. Based on the measurement results, it is known that most of the 21 respondents (65.2\%) are in the category of not being able to master fine motor skills.

Based on the data that has been obtained, the number of male respondents is far more than female respondents. A total of $57.1 \%$ of respondents were male, while the rest $(42.9 \%)$ were female. Meanwhile, the difference in the level of fine motor skills between male and female respondents was barely noticeable. This finding is similar to the results of research by Pahlvanian and Ahmadizadeh (2014) on the relationship between gender and fine motor skills in preschool children. In this study it was found that in general there was no significant difference between male and female respondents. However, if we look closely, male respondents are superior in gross motor skills and female respondents are superior in fine motor skills.
Quoted from Susilaningrum (2014) Soetjiningsih stated that there are several factors that can affect the level of child development. one of them is gender. In theory, it is said that girls experience more rapid development at a younger age, while boys will only experience rapid development at an older age. In other words, the growth and development of boys and girls have different periods of acceleration. In fact, according to Zaidi (2010) women experience the development of the frontal lobe or the part that regulates fine motor skills 6 years earlier than men.

However, these theories do not explain in detail from what age boys and girls begin to experience growth spurts. This indirectly explains why the findings in the field do not show a clear difference between male and female respondents. In addition to these factors, there are other factors that can also affect a child's fine motor skills such as the environment and the fulfillment of children's basic needs. It could be that if the research was conducted on respondents with an older age group in different environments it could show different results.

Table 4.2 explains that most of the respondents' parents (60.8\%) are junior high school graduates. In addition to gender, another factor that can affect a child's growth and development is parental education. Based on the results of research conducted by Patra, et al (2016) showed that the education level of parents, especially mothers can predict the level of cognitive, motor, and language development in children. Furthermore, the study also explains that the level of parental education affects children's neurocognitive abilities both internally and externally. Children born to mothers with higher education tend to have an IQ of 14.2 points higher than children born to mothers with low education.

After measuring fine motor skills, the researchers then provided stimulation to play using Kinetic Sand for 3 weeks. Respondents were divided into 3 small groups. Stimulation was carried out for 9 meetings and was accompanied by the homeroom teacher. Each meeting is packed with a variety of different themes, including the theme of building shapes, getting to know various kinds of animals, fruits, flower shapes, making 
letters and numbers, hunting for treasures, playing cooking, and making racing circuits. This aims to avoid boredom that can occur in children.

After being stimulated for 3 weeks, the respondent's fine motor skills were measured again so that it could be seen whether the activity had an effect or not. From the measurement results, $80.95 \%$ of respondents have good fine motor skills and $19.05 \%$ are in the sufficient category. In other words, there was an increase in the respondent's fine motor skills after receiving stimulation. This is in accordance with the opinion of Maryunani (2014) that the developmental ability of children depends on the opportunity to learn and practice children. In this case, the provision of stimulation using Kinetic Sand increases children's learning and practice opportunities, especially in the fine motor aspect.

Wilcoxon's Signed Rank Test statistical test results show that -value has a value of 0.000 . Because the value $-<0.05$, it can be said that the use of kinetic sand as a stimulation medium affects the fine motor development of preschool children.

Siddik (2015), says that educational game tools have a significant positive relationship to the development of children aged 3-5 years. The development that occurs is in accordance with the form of stimulation provided by the game tool. In this study, Kinetic Sand was chosen as the stimulation medium because apart from being relatively new, this sand has a smooth texture and is easy to shape. In addition, this sand has a variety of colors so that it is more attractive to children. The use of Kinetic Sand can stimulate the development of the nervous system around the fingers and palms of children to become more mature and allow children to carry out more complex activities using their hands.

According to Susilaningrum (2013), sensory stimuli provided by the environment will be responded to by showing motor activity. Sensory stimulation received by the child's fingertips when playing with kinetic sand stimulates the child to respond in the form of movements that involve eye, finger, and hand coordination. Responses that arise include squeezing, grasping, pinching, twisting, and pressing the surface of the sand. Giving stimulus regularly and continuously increases the maturity of the brain's nervous system which regulates the muscles around the child's hands and fingers. This development allows the muscles of the hands and fingers to develop so that they are able to perform more complex activities.

\section{CONCLUSIONS}

Before being given stimulation using kinetic sand, most of the respondents $(65.2 \%)$ had not been able to master fine motor skills and a small proportion $(9.5 \%)$ were classified as capable. After being given stimulation using Kinetic Sand, it showed that most of the children $(73.91 \%)$ were in the already capable category. Wilcoxon's Signed Rank Test statistical test results show that -value has a value of 0.000 . Because the value $-<0.05$, it can be said that the use of kinetic sand as a stimulation medium affects the fine motor development of preschool children.

\section{REFERENCES}

Adriana, Dian. 2013. Tumbuh Kembang dan Terapi Bermain Pada Anak. Jakarta: Salemba Medika.

Balci, Nilay Comuk. Dkk. 2015, Screening Preschool Children for Fine Motor Skills: Environmental Influence. The Journal of Physical Therapy Science. Vol.28, No.3, hlm. 1026-1031.

Calypso. 2016. Mainan Pasir Anak Kinetic Sand Indonesia dari Waba Fun, Swedia. Diambil dari

http://calypso.co.id/index.php?route=pavblo g/blog\&id=15. (22 Desember 2017).

Faizuddin, Mohammad. 2015. Pembelajaran PAUD. Bandung: Remaja Rosdakarya.

Hidayat, A. Alimul Aziz. 2013. Pengantar Ilmu Kesehatan Anak untuk Pendidikan Kebidanan. Jakarta: Salemba Medika.

Marmi dan Kukuh Rahardjo. 2015. Asuhan Neonatus, Bayi, Balita, dan Anak Prasekolah. Yogyakarta: Nuha Media.

Medise, Berniye Endriyani. 2013. Mengenal Keterlambatan Perkembangan Umum pada Anak (http://idai.or.id/publicarticles/seputar-perkembangananak/mengenal-keterlambatan- 
perkembangan-umum-pada-anak.html. ( 12 Januari 2018

Melinda. 2013. Pengaruh Melukis Menggunakan Teknik Finger Painting Terhadap Keterampilan Motorik Halus Pada Taman Kanak-Kanak. Skripsi. FIP, Pend. Guru Pendidikan Anak Usia Dini Universitas Pendidikan Indonesia.

Notoatmodjo, S. 2010. Metodologi Penelitian Kesehatan. Jakarta Rineka: Cipta

Nurlita, Ida. 2010. Faktor Resiko gangguan motorik pada anak (online) http://google.com/html) (15 Januari 2018).

Pahlevanian A.A, dan Ahmadizadeh Z., 2014. Relationship between Gender and Motor Skill in Preschoolers. Middle East J Rehabil Health. 1(1) :1

Patra, Kousiki, dkk. 2016. Maternal Education Level Predicts Cognitive, Language, and Motor Outcome in Preterm Infants in the Second Year of Life. Am J Perinatol. Vol.33, No.8, Hlm.738-744.

Permendikbud No. 137, 2014. Standar Nasional Pendidikan Anak Usia Dini. Jakarta

Ridha, H. Nabiel. 2014. Buku Ajar Keperawatan
Anak.Yogyakarta: Pustaka Pelajar

Ruth. 2017. Moms, Ini 6 Manfaat Kinetic Sand yang Sedang Booming!. Diambil dari https://www.blibli.com/friends/blog/manfaa t-kinetic-sand/. (22 Desember 2017).

Setiadi. 2013. Konsep dan Praktek Penulisan Riset Keperawatan, Edisi2. Yogyakarta: Graha Ilmu.

Setiawan dan Saryono. 2011. Metodologi Penelitia Kebidanan DIII, DIV, S1, dan S2. Yogyakarta: Nuha Media.

Suherman. 2012. Buku Saku Perkembangan Anak. Jakarta : EGC

Sunarya, Eka K. S. 2017. 5 Aspek Dasar Pengembangan Anak Usia Dini (htpp://ibufoundation.or.id/index.php/2017/ 06/125-aspek-dasar-pengembangan-anakusia-dini/

Susilaningrum, R. 2014. Asuhan Keperawatan Bayi dan Anak untuk Perawat dan Bidan Edisi 2. Jakarta: Salemba Medika.

Zaidi, Zeenat F. 2010. Gender Differences in Human Brain: A Review. The Open Anatomy Journal. Vol-2, hlm.37-55. 